Available online at https://jurnal.stmikroyal.ac.id/index.php/jurdimas

\title{
MENINGKATKAN KREATIFITAS DAN INOVASI MELALUI PERMAINAN MAKE SOMETHING BEAUTIFUL
}

\author{
Paramita Nuraini $^{1}{ }^{*}$, Subiyanto ${ }^{1}$, Nofi Nur Yuhenita ${ }^{1}$ \\ Program Studi Bimbingan Konseling, Fakultas Keguruan Ilmu Pendidikan, \\ Universitas Muhammadiyah Magelang \\ e-mail: paramitanuraini@ummgl.ac.id
}

\begin{abstract}
The low creativity of students at Muhammadiyah High School in Magelang is the background in this service. This lack of creativity is related to creativity in thinking and creativity. Many students do not participate in teaching and learning activities as much as passive and monotonous students in learning. This dedication uses innovative Guidance Counseling media that is using the game "Make Something Beautiful". The target of this service is Muhammadiyah 1 High School students in Magelang City. Assistance is done by devotees to monitor the extent to which this dedication can increase student creativity. in the first stage which covers the Importance of Creativity for Students and Impacts for someone who lacks creativity, students begin to understand the importance of creativity and innovation in this 4.0 era.
\end{abstract}

Keywords: innovation creativity; make something beautiful.

\begin{abstract}
Abstrak: Rendahnya kreativitas siswa di SMA Muhammadiyah Magelang ini terkait degan kreativitas berpikir dan kreativitas bersikap. Banyak siswa yang kurang berpartisipasi dan kepercayaan diri dalam kegiatan belajar mengajar seperti halnya siswa pasif dan monoton dalam pembelajaran. Pengabdian ini menggunakan media Bimbingan Konseling yang inovatif yakni mengggunakan permainan "Make Something Beautiful". Target dari pengabdian ini adalah siswa SMA Muhammadiyah 1 Kota Magelang. Pendampingan dilakukan pengabdi untuk memantau sejauh mana pengabdian ini dapat meningkatkan kreatifitas siswa. pada tahap pertama yang meliputi Pentingnya Kreatifitas Bagi siswa dan Dampak Bagi seseorang yang tidak memiliki kreatifitas, siswa mulai memahami pentingnya kreatifitas dan inovasi dalam era 4.0 ini.
\end{abstract}

Kata kunci: inovasi ; kreativitas; make something beautiful.

\section{PENDAHULUAN}

Kreativitas adalah kemampuan menciptakan dan mewujudkan gagasan baru untuk meningkatkan nilai tambah atau manfaat dari bahan-bahan yang sudah tersedia (Sahren, 2020). Sikap ini memiliki peranan yang sangat penting karena memberikan berbagai manfaat bagi kehidupan manusia. Hal ini akan menentukan pola pikir dan karakter seseorang sehingga memberikan andil yang sangat besar dalam setiap kesuksesan.

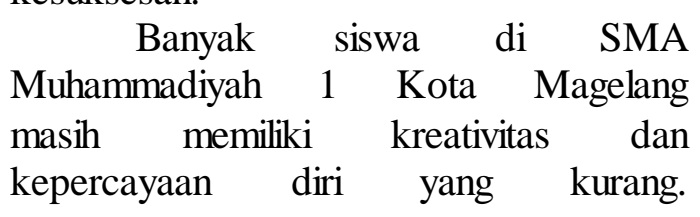


Available online at https://jurnal.stmikroyal.ac.id/index.php/jurdimas

Berdasarkan wawancara yang dilakukan diketahui masih banyak siswa yang pasif, terlihat dari banyak siswa yang belum maksimal dalam mengembangkan ide-ide kreatif jika ditanya oleh guru, jawaban masih monoton. Tidak berani untuk menyampaikan pendapat karena takut salah. Cara berpikir belum fleksibel masih monoton. Oleh karena itu, pengabdi akan memberikan solusi terhadap permasalahan tersebut melalui metode permainan.

Permainan merupakan metode yang sesuai untuk belajar keterampilan sosial, karena dengan permainan akan tercipta suasana yang santai dan menyenangkan, suasana tersebut dapat mempermudah dalam memecahkan masalah, mengambil keputusan, merencanakan sesuatu dan berkomuni-kasi dengan baik sehingga memperkuat kepribadian serta meningkatkan kepercayaan diri seseorang, serta kreativitas seseorang. (Ahman, 1998), disimpulkan bahwa model bermain peran efektif untuk dijadikan model bimbingan dalam mengembangkan keterampilan sosial anak berkemampuan unggul. Hal tersebut senada dengan penelitian (Howard, 2010) yang menyebutkan bahwa kepercayaan diri pada siswa dapat ditingkatkan melalui permainan, karena melalui permainan akan dapat membentuk sebuah dinamika kelompok yang efektif.

Terdapat banyak sekali media permainan yang bisa digunakan sebagai sarana untuk meningkatkan kreativitas siswa salah satunya adalah dengan permainan "make something beautiful". Media permainan ini diharapkan nantinya mampu membantu dalam meningkatkan kreativitas siswa karena didalamnya terdapat beberapa nilai yang dapat dipetik, mulai dari komunikasi antar sesama, berani mengemukakan ide-ide didepan umum.

\section{METODE}

Pengabdian yang dilakukan oleh pengabdi dilaksanakan di SMA Muhammaddiyah 1 kota Magelang. Di ikuti 30 siswa siswi SMA Muhammadiyah 1 Kota Magelang. Ada tiga metode yang diterapkan dalam pelatihan ini, yaitu metode penyuluhan, pelatihan, dan pendampingan. Adapun langkah yang telah ditempuh dalam kegiatan pengabdian ini mencakup beberapa tahap berikut ini.

\section{Persiapan}

Tahap persiapan merupakan tahap awal sebelum pelaksanaan PKU. Dalam tahap ini ada beberapa hal yang dilakukan, yakni koordinasi internal, dilakukan oleh Tim untuk merencanakan pelaksanaan secara konseptual, operasional, serta job description masing-masing anggota, penentuan dan recruitment peserta pelatihan.

\section{Pelaksanaan}

Pelaksanaan pelatihan Tahap ini merupakan tahap pelatihan yang diberikan kepada siswa SMA Muhammadiyah 1 kota Magelang. Pelaksanaan pelatihan ini mencakup beberapa hal berikut.

\section{a. Penyajian Materi}

Materi yang disajikan terkait kreatifitas siswa, manfaat kratifitas bagi diri dan lingkungan dan dampak dalam kurangnya kratifitas bagi siswa. Pen- yajian ini diploting dalam 3 hari tatap muka. Penyajian materi adalah tim pengabdian sendiri disesuaikan 
Available online at https://jurnal.stmikroyal.ac.id/index.php/jurdimas

dengan bidang keahlian masingmasing. Mate- ri yang tersajikan sebanyak 3 (tiga) bahasan yang masing-masing disajikan oleh anggota Tim Pengabdian. Berikut table daftar materi dan pematerinya yang dilaksanakan dalam program PKU ini.

b. Penugasan Praktik

Siswa diberikan pelatihan berupa permainan dengan menggunakan "make something beautiful " untuk meningkat kan kreatifitas siswa

\section{PEMBAHASAN}

Antusiasme peserta dalam kegiatan pengabdian tersebut terlihat dari peserta yang aktif dan mengikuti kegiatan dari awal sampai akhir tanpa ijin meninggalkan kegiatan pengabdian tersebut.

Adapun langkah-langkah dalam kegiatan permainan adalah sebagai berikut (Imania, 2011):

1. Masing-masing kelompok diberikan satu bendel kertas koran bekas

2. Ketua kelompok diberikan instruksi permainan

3. Kelompok diberikan waktu 1 menit untuk merundingkan karyanya

4. Kelompok harus membuat suatu karya dari barang berkas yang disiapkan dengan alokasi hanya 20 menit

5. Setelah selesai, masing-masing kelompok menceritakan hasil karyanya

6. Permainan dilaksankan dalam keadaan tutup mulut,bias menggunkan kode-kode yang disepakati.
7. Evaluasi atau refleksi;

8. Adakah peserta yang mendominasi dalam ke- lompoknya?

9. Adakah peserta yang tid- ak ikut dalam aktifitas dinamika kelompok?

10. Adakah yang melanggar peraturan?

11. Learning Point yang diperoleh

Permainan ini memanfaatkan

barang bekas bertujuan memotivasi siswa untuk mengeluarkan idenya sehingga tercipta suatu karya yang bagus, indah dan berseni. Hal ini menunjukkan bahwa satu barang bekas, meskipun hanya sebuah barang bekas dapat bermanfaat kembali dan diperlukan pemikiran yang berarti dalam kelompoknya. Hal ini tentunya membutuhkan pribadi kepemimpinan yang baik dari ketua kelompoknya untuk mengatur anak kelompoknya mencurahkan kegiatan dari dirinya. Apabila ketua kelompok bersikap otoriter, mungkin yang terjadi kekakuan dalam memimpin jalannya permainan, namun bisa juga seorang ketua sangat liberal sehingga terjadi keributan dalam mengatur emosi anak kelompoknya.

Kelompoknya yang anggotanya sudah saling mengenal, akan memudahkan jalannya permainan. Situasi akan ramai dan menyenangkan. Masing-masing angggota akan leluasa mencurahkan idenya agar sama-sama menghasilkan satu karya yang sempurna. Namun kejadiannya akan terjadinya sebaliknya, apabila para anggota belum mengenal teman lainnya, adanya rasa malu untuk mengungkapkan keinginannya, sehingga mengalami kebuntuan ide. Keadaan ini membutuhkan seorang pemimpin kelompok yang mampu menguasai situasi kelompoknya.

Anggota kelompok diberikan hak penuh untuk membentuk karya kelompoknya, sehingga diperlukan ker- 
Jurdimas (Jurnal Pengabdian Kepada Masyarakat) Royal

Vol. 3 No. 2, Juli 2020, hlm. 111 - 114

DOI: https://doi.org/10.33330/jurdimas.v3i2.490

ISSN 2622-3813 (Online)

Available online at https://jurnal.stmikroyal.ac.id/index.php/jurdimas

jasama yang baik juga komunikasi yang efektif, sehingga diperlukan kerjasama yang baik juga komunikasi yang efektif antar anggota. Dengan memanfaatkan waktu yang sempit itu menjadikan para anggota benar-benar berfikir ekstra keras demi mewujudkan hasil karyanya.

Di dalam permainan dinamika kelompok ini, tetap menggunakan peraturanperaturan yang telah ditetapkan yaitu (1) waktu yang disediakan hanya 20 menit, (2) tidak bole ada yang bersuara/hanya dengan kode-kode, (3) tidak menggunakan bahan-bahan laian seperti gunting, lem, pensil dll, jadi semua kelompok berpegang pada norma permainan ini.

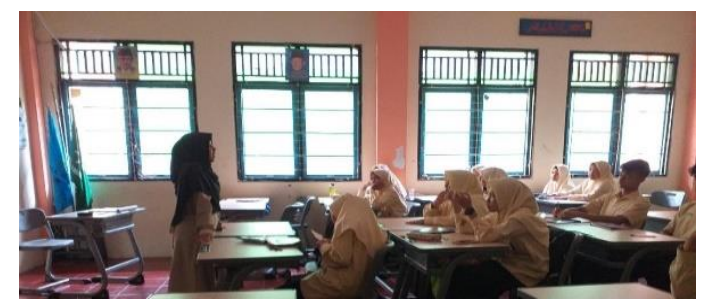

Gambar 1. Penyajian Materi Kreativitas

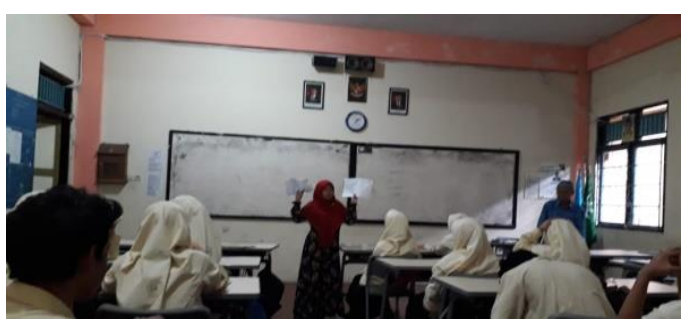

Gambar 2. Praktik Kegiatan PKM

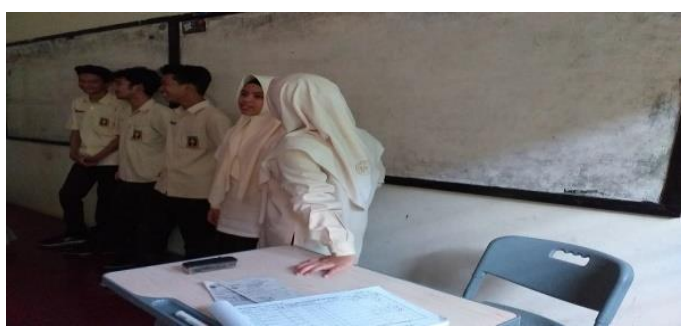

Gambar 3. Presentasi Kelompok

Akhir dari kegiatan ini adalah menceritakan maksud dan tujuan dari bentuk karya yang dihasilkan masingmasing kelompok dan diberikan penilaian atas karyanya. Bagaimanapun juga hasil penilaian dari tim juri harus diterima, ada yang kalah dan ada yang menag, namun pada prinsipnya adalah semua menjadi pemenang dari berbagai segi manusia, sisi kepemimpinan, sisi kedisiplinan, sisi social, sisi ambisi, sisi toleransi dan sisi kemanusiaan lainnya.

\section{SIMPULAN}

Simpulan dari kegiatan pengabdian ini adalah siswa memiliki pemahaman terkait pentingnya kreativitas dalam pembelajaran dan kehidupan bermasyarakat.

\section{DAFTAR PUSTAKA}

Ahman. (1998). Bermain Peran Sebagai Model Bimbingan Dalam Mengembangkan Ketrampilan Sosial Anak Berkemampuan Unggul. Bandung: IKIP.

Howard, J. (2010). Game Techniques in improving the understanding, planning and practing selfconfidence. Mc Graw Hill: Open University.

Imania, S. \&. (2011). 55 permainan (Game) dalam Bimbingan dan Konseling. Yogyakarta: Pramita.

Sahren, S., Irianto, I., \& Akmal, A. (2020). MEMBANGUN KREATIFITAS PEMUDA MILENIAL MELALUI KONTEN VIDEO MULTIMEDIA KOMPUTER. Jurdimas(Jurnal Pengabdian Kepada Masyarakat)Royal, 3(1), 75-80. 